Zbyszek Dymarski*

ORCID: 0000-0002-3637-2661

Gdańsk

\title{
Wewnętrzna przestrzeń wolności a sprawa człowieka w ujęciu Józefa Tischnera**
}

\section{Sprawa czlowieka}

Bardzo ważne miejsce w refleksji Józefa Tischnera nad „sprawą człowieka"1 zajmuje kwestia wolności. Posługując się terminem „sprawa człowieka", chce filozof wskazać na szczególną pozycję człowieka w świecie, związaną z samoświadomością istnienia i przemijania w czasie. Tischnerowi chodzi zatem o to, by na człowieka nie patrzeć tak, jak na jedną z wielu rzeczy, lecz by dostrzec, że jest on czymś, a raczej kimś radykalnie innym. By odkryć, jak niepowtarzalną i w jakim stopniu autonomiczną jest istotą. Ważnym działaniem na rzecz rozpoznania sprawy człowieka jest też poznanie, jak sam człowiek doświadcza siebie, a jak świata. Istotnym składnikiem takiego poznania jest również zrozumienie, że człowiek sam interpretuje re-

* Dr inż. Zbyszek Dymarski jest adiunktem w Instytucie Badań nad Kulturą Uniwersytetu Gdańskiego (Wydział Filologiczny). Adres: Instytut Badań nad Kulturą UG, ul. Wita Stwosza 55, 80-308 Gdańsk; e-mail: finzd@ug.edu.pl.

** Tekst przygotowany w ramach grantu „Józef Tischner - polska filozofia wolności a myśl europejska” (Narodowy Program Rozwoju Humanistyki - 11H 130471 82), realizowanego przez Instytut Myśli Józefa Tischnera w Krakowie.

1 Józef Tischner, „Filozofia i ludzkie sprawy człowieka”, w: Józef Tischner, Świat ludzkiej nadziei (Kraków Znak, 1994), 109-125; Józef Tischner, „Sprawa osoby - wstępne przybliżenie", Logos i Ethos 2 (1992): 5-19. 
zultaty tych doświadczeń. Tischner uważa też, że aby rozpoznać prawdziwie człowieka, należy zmienić dotychczasowy sposób myślenia i mówienia o człowieku. Dlatego badacz człowieka nie powinien odwoływać się do modeli interpretacyjnych wypracowanych przy badaniu świata rzeczy. Powinien też posługiwać się językiem możliwie „ludzkim”, to znaczy pozbawionym uprzedmiotowień.

Rozpoznanie tego, czym jest wolność, było jednym z pierwszych tematów, z którymi Józef Tischner mierzył się jako młody filozof. W swych badaniach tej kwestii odnosił się do wielu myślicieli. Byli wśród nich Erich Fromm, Martin Heidegger, Søren Kierkegaard, Paul Ricoeur. Ale jego własne rozumienie wolności rodziło się w konfrontacji z poglądami trzech innych wielkich myślicieli. Byli to Tomasz z Akwinu, Jean-Paul Sartre i Georg Wilhelm Hegel.

W tekstach Tischnera jest wiele nawiązań do ich filozofii. Nie systematyzuje on jednak ani nie streszcza ich poglądów. Wybiera sobie te wątki, które $\mathrm{z}$ jego punktu widzenia są ważne. $\mathrm{Z}$ niektórymi polemizuje, inne wykorzystuje, ale często też niektóre z nich po swojemu modyfikuje ${ }^{2}$.

\section{Wobec wolności w ujęciu Tomasza z Akwinu}

Najostrzej polemizował Tischner z realizowanym przez Tomasza z Akwinu sposobem myślenia o wolności. Widać to już w tekstach powstałych w latach sześćdziesiątych. Ale dopiero wielka debata z tomistyczną szkołą lubelską ${ }^{3}$ ujawniła w pełni jego krytyczny stosunek do tomizmu i przyczyniła się do krystalizacji jego własnych poglądów.

2 To podejście Jan Andrzej Kłoczowski komentował następująco: „Taka jest lektura filozofa. Tischner nie był profesorem filozofii, był filozofem. To bardzo ważna rzecz: jego język, przy całej świeżości i nowoczesności, był przecież bardzo mocno zakorzeniony w tradycji, był zakorzeniony w dziedzictwie, ale służył mu do opisania jego doświadczenia świata. Jego hermeneutyka nie była hermeneutyką tekstów, chociaż ona też jest bardzo ważna - była hermeneutyką człowieka". [Jan Andrzej Kłoczowski, Marek Drwięga, Karol Tarnowski, Jarosław Makowski, „Filozofia z wnętrza metafory”, Kontrapunkt (dodatek do Tygodnika Powszechnego) 10 (2000), (19.11.2000): 12-13] podobne obserwacje miał Ryszard Panasiuk [„Ksiądz Tischner czyta Hegla”, w: Pytając o człowieka - myśl filozoficzna Józefa Tischnera, red. Władysław Zuziak (Kraków: Znak, Wydział Filozoficzny Papieskiej Akademii Teologicznej, 2002), 33-42].

3 Toczyła się ona w latach 1970-1980 na łamach bardzo opiniotwórczych wówczas czasopism, takich jak Tygodnik Powszechny, Znak. [Zob. też: Zbyszek Dymarski, „Debata księdza Józefa Tischnera ze szkołą lubelską", Logos i Ethos 1 (1998): 235-245]. 
Główna oś sporu dotyczyła ówczesnej intelektualnej kondycji chrześcijaństwa. Tischner był przekonany, że za kryzys chrześcijaństwa ${ }^{4}$ odpowiada pewna jego wersja interpretacyjna. Uważał, że tomizm błędnie ujmuje rzeczywistość i podsuwa nieadekwatne sposoby interpretacji treści religijnych $^{5}$. Stosowane przezeń sztywne schematy pojęciowe zniekształcają świat i uniemożliwiają widzenie go w jego aksjologicznych wymiarach. Ta koncepcja filozoficzna, zdaniem autora Schyłku chrześcijaństwa tomistycznego, nie dysponuje ani językiem, ani metodologią zdolną do adekwatnego wyrażenia doświadczenia wiary i wielu innych, fundamentalnych dla chrześcijaństwa, zagadnień teoretycznych. Tischner uważał, że fałszujące dla przesłania chrześcijańskiego Objawienia jest wyjaśnianie go za pomocą kategorii zapożyczonych jeszcze z filozofii Arystotelesa. Błędne są też i inne, oparte na tomizmie, interpretacje elementów doktryny chrześcijańskiej, takich jak na przykład natura eucharystii i działanie łaski uczynkowej na człowieka.

Uzasadnienie polemicznego stanowiska względem tych kwestii nie mogło obejść się bez odniesienia się do kwestii natury człowieka i charakteru jego wolności. Dla Tomasza z Akwinu wolność jest tylko jedną z władz pożądawczych człowieka i jest wolnością jego (to jest człowieka) woli. A wola z natury skierowuje się na dobro. To przekonanie Étienne Gilson streścił w następujący sposób: ,wola pożąda w sposób konieczny dobra w ogólności; ta konieczność oznacza to jedynie, że wola nie może nie być sobą i że to niezmienne dążenie do dobra jako takiego stanowi pierwszą zasadę wszystkich jej czynności”' . W tym pragnieniu dobra kieruje się ona rozumem. To znaczy rozum podsuwa woli różne warianty realizacji dobra. A wolność polega tu jedynie na wybieraniu pomiędzy tymi możliwościami realizacji dobra.

Tischner uważa, że taki sposób rozumienia wolności jest nieprawdziwy z trzech powodów. Po pierwsze, tak zdefiniowana wolność nie jest w pełni wolna, realizować się bowiem może jedynie w pewnym obszarze. Po tomistycznemu definiowana wolność nie potrafi przekroczyć wyznaczonego jej

${ }^{4}$ Dostrzegany przez niego tak na zachodzie Europy (w 1968 roku był na rocznym stypendium w Louven, potem także kilkakrotnie wyjeżdżał na Zachód, choć na krócej), jak i w Polsce, choć tu bardziej w wymiarze intelektualnym niż socjologiczno-duszpasterskim.

${ }_{5}^{5}$ Pisał: „to nie religia, lecz właśnie wplątana w religię pewna konkretna filozofia legła u podstaw większości sytuacji, które określamy dzisiaj mianem kryzysowych. Kryzys nie jest kryzysem chrześcijaństwa. Jest to kryzys pewnej historycznej wersji interpretacyjnej chrześcijaństwa” [Józef Tischner, „Schyłek chrześcijaństwa tomistycznego”, Znak 1 (1970): 14].

${ }^{6}$ Étienne Gilson, Tomizm. Wprowadzenie do filozofii św. Tomasza z Akwinu, thum. Jan Rybałt (Warszawa: Instytut Wydawniczy PAX, 1960), 340. 
celu. Wybiera tylko środki do celu, a nie sam cel. Co więcej, Bóg poprzez „naturę” woli, czyli rozum, może oddziaływać na wolność. To oznacza według Tischnera, że nie jest ona (w takim ujęciu) wolnością w pełni, czyli wolnością radykalną ${ }^{7}$ Po drugie, tak zdefiniowana wolność jest racjonalna tylko na gruncie tomistycznego rozumienia racjonalności. A to oznacza, że nie może być na tyle radykalna, by wybrać dobro, które wymyka się tomistycznemu rozumowi. Taką sytuacją jest według Tischnera na przykład ofiara za innego. Trzecia racja nie jest związana $\mathrm{z}$ wykazywaniem niezgodności tomistycznych koncepcji z doświadczeniem wolności, ale z pytaniem o fundamenty człowieczeństwa. Dla autora Sporu o istnienie człowieka, fundamentem człowieka nie jest substancjalna bytowość, lecz wolność sama.

I w tym aspekcie bliska Józefowi Tischnerowi wydaje się filozofia Jean-Paula Sartre'a, ale nie do końca.

\section{Wobec wolności w ujęciu Jean-Paula Sartre'a}

Jean-Paul Sartre to ważny dla teorii i praktyki wolności myśliciel. To on oraz artykułowane przezeń idee były natchnieniem dla ruchu kontrkulturowego oraz dla studentów buntujących się w maju 1968 roku w Paryżu i w innych akademickich miastach Zachodu. Także dla Józefa Tischnera sposób myślenia Sartre'a o wolności był inspirujący, ale dodać trzeba od razu, że polski filozof nie był wobec niego bezkrytyczny.

Tischner uważał, że zarówno Jean-Paul Sartre, jak i Tomasz z Akwinu myślą o wolności w ramach dyskursu ontologicznego, to bowiem kategoria bytu jest dla nich podstawowym punktem odniesienia. Dla Tomasza wolność jest siłą pożądawczą bytu myślącego, a dla Sartre’a jest to bytowa nicość. Ale na tym podobieństwa się kończą.

Według autora Bytu i nicości człowiek może przeżywać swoje życie na dwa sposoby. Albo jako byt-w-sobie, albo jako byt-dla-siebie. Byt zrealizowany, byt spełniony, zupełny, byt, w którym nic się nie wydarza, to byt-w-sobie $^{8}$. Takim bytem jest na przykład kamień, stół albo drzewo. Człowiek, by

${ }^{7}$ Dlatego świadom znaczenia wolności dla człowieka Zachodu, Tischner pisał że: „Nie możemy jednak zgodzić się z tezą, że to właśnie tomistyczne myślenie o wolności ma być wzorem i lekarstwem dla współczesnych" [Józef Tischner, Spór o istnienie człowieka (Kraków: Znak, 1998): 162].

8 „Taka adekwatność, charakteryzująca byt-w-sobie została wyrażona prostą formułą: byt jest tym, czym jest. W bycie-w-sobie nie istnieje żadna cząstka bytu, która byłaby zdystanso- 
być człowiekiem, powinien funkcjonować inaczej, powinien wybierać. Wybieranie ma charakter fundamentalny dla ludzkiej egzystencji. Ludzki sposób istnienia Sartre określa jako byt-dla-siebie. Człowiek staje się takim bytem dzięki temu, że wybiera. Nie treść wyborów, ale sam fakt wybierania jest tu decydujący. Byt-dla-siebie istnieje nie na sposób rzeczy, lecz na sposób twórczy, podejmując decyzje i realizując je w czasie. Jego wyborów nie poprzedzają żadne uprzednie plany, reguły prawne czy też jakiekolwiek zasady moralne. I dlatego człowiek może stawać się tym, czym sam siebie czyni. Dlatego w przypadku człowieka Sartre głosi, że egzystencja poprzedza esencję. W rozprawie Egzystencjalizm jest humanizmem pisze obrazowo: „Człowiek jest przede wszystkim projektem przeżywanym subiektywnie, miast być pianą, pleśnią czy kalafiorem. Przed projektem nic nie istnieje uprzednio, nic nie istnieje innego w sferze poznawalności. Człowiek przede wszystkim będzie tym, co stanowi realizację jego woli"”.

Należy zauważyć, że w rezultacie wyboru człowiek zaczyna się tworzyć, ale w imię wolności przy następnym wyborze te rezultaty musi porzucić, by ten nowy wybór także nie był przez nic warunkowany. Dlatego Tischner, chcąc w krótkim zdaniu streścić pogląd Sartre'a na wolność, powiedział, że dla Francuza jest to ,'nicość' pomieszczona w głębi świadomości"10. Bo to, co najważniejsze - to, co waży i decyduje o tym, kim się jest i co się wybiera - jest nicością, pustką, czyli nie-bytem.

W rezultacie takich działań wyniki wyborów nie urzeczowiają człowieka. One stanowią świadomość, która jest nie-bytem. Można powiedzieć, że one stanowią pewną warstwę pamięci, która bytem nie jest. Wolność jest tutaj źródłem negacji. Tylko przy takim rozumieniu wnętrza człowieka wolność nie jest kierowana przez zastane reguły. Wolność może być sobą, czyli wolnością prawdziwą, gdy wybiera poza wszelkimi uwarunkowaniami, „tryskając” nagle z niebytu ku bytowi, który dopiero ma zaistnieć. Byt-dla-siebie jest „,bytem, który nie znajduje żadnej pomocy, żadnego punktu oparcia w tym, czym był. Ale przeciwnie: byt-dla-siebie jest wolny i może sprawić, że świat jest, ponieważ jest bytem, który ma być tym, czym był

wana w stosunku do siebie" [Jean-Paul Sartre, Byt i nicość, tłum. Jan Kiełbasa i in. (Kraków: Zielona Sowa, 2007): 116].

9 Jean-Paul Sartre, Egzystencjalizm jest humanizmem, thum. Małgorzata Kowalska, Janusz Krajewski (Warszawa: Altaya \& DeAgostini, 2001): 132.

10 Tischner, Spór, 55. 
w świetle tego, czym będzie. Wolność bytu-dla-siebie ukazuje się więc jako jego byt"11.

Tak pojęta wolność, choć radykalna i fundamentalna dla sprawy człowieka, również Tischnerowi nie odpowiada. Niszczy ona bowiem wszelkie więzy i relacje wspólnotowe. Separacja bowiem to druga strona wolności. Można też powiedzieć - cóż z tego, że wolni, skoro samotni.

\section{Wobec wolności w ujęciu Georga Wilhelma Friedricha Hegla}

Bardzo uważnie Fenomenologię ducha czytał Józef Tischner w smutnych latach stanu wojennego ${ }^{12}$. Czytał ją dokładnie i - jak wyznaje - kilkukrotnie, uznał bowiem, że to, co pisał Hegel w początkach XIX wieku, może być ważne również w końcu wieku XX. Czytał „ze siebie i dla siebie”13, bo wierzył, że zawarte tam idee pozwolą mu lepiej zrozumieć otaczającą go rzeczywistość i uwikłanego w nią człowieka ${ }^{14}$. Najwięcej śladów tych intelektualnych zmagań z myślą Georga Wilhelma Friedricha Hegla znaleźć można w książkach Spowiedź rewolucjonisty i w Sporze o istnienie człowieka. A także w wydanych niedawno wykładach - głoszonych w pierwszych miesiącach stanu wojennego - poświęconych analizie filozofii Hegla, a szczególnie jego Fenomenologii duch $a^{15}$.

Swoje zrozumienie heglowskiej koncepcji człowieka oparł Józef Tischner na analizie opowieści o wzajemnych zmaganiach pana i niewolnika ${ }^{16}$.

${ }_{11}$ Sartre, Byt, 583.

12 Zapisy tego namysłu nad tekstami Hegla były w latach 1987-1992 drukowane w niezależnym miesięczniku Res Publika, a potem zebrane w postaci książkowej jako Spowiedź rewolucjonisty (Kraków: Znak, 1993).

13 Tamże, 8.

14 „Hegel stara się rozumieć, idąc «od góry» - od idei do faktów. Idee bez faktów są bezsilne, fakty bez idei są ślepe. Podstawowym faktem historii jest człowiek. Zrozumieć historię, to znaczy zrozumieć człowieka - ale i na odwrót: zrozumieć człowieka, to zrozumieć historię jego idei i jego czynów" [Tischner, Spowiedź, 5].

15 Józef Tischner, „Rozważania wokół Hegla”, w: Józef Tischner, Etyka a historia. Wykłady, red. Dobrosław Kot (Kraków: Znak, 2008), 1-210. Wykłady te rozpoczął Tischner głosić w październiku 1981 roku, ale na skutek studenckich strajków, a potem ogłoszenia stanu wojennego, mógł je kontynuować dopiero w semestrze wiosennym 1982 roku.

16 Georg Wilhelm Friedrich Hegel, Fenomenologia ducha, t. 1, thum. Adam Landman (Warszawa: Państwowe Wydawnictwo Naukowe, 1963), 221-228. 
W rozjaśnianiu heglowskich opisów kondycji ludzkiej były Tischnerowi pomocne komentarze znakomitych znawców myśli niemieckiego filozofa, Aleksandra Kojève' $\mathrm{a}^{17}$ i Jeana Hyppolite' $\mathrm{a}^{18}$.

Człowiek, byt-dla-siebie, walczy na śmierć i życie z innym bytem-dla-siebie o uznanie. Zdaniem Hegla człowiek nie rodzi się wolny i dlatego wolność jest dla niego zadaniem, a nie stanem zastanym. By jeden był wolny, potrzebny jest drugi, który tę wolność uzna. Zrobi to, gdy zostanie do tego zmuszony w walce. Bardziej waleczny, gotów zaryzykować własne życie, zwycięży. Wolność pana płynie z uznania jej przez niewolników, czyli tych, co ulegli w obliczu zagrożenia śmiercią. Ale też częściowa wolność niewolników wymaga uznania ze strony pana.

Pan, zyskawszy uznanie niewolników, włada nimi poprzez dobra, których pożądają niewolnicy, a którymi on dysponuje. By żyć, niewolnik potrzebuje jedzenia, picia, dachu nad głową, opieki... Pożądania są tym, co wiąże pana i niewolnika. Poprzez uznanie kogoś z zewnątrz człowiek zyskuje świadomość, że jest kimś, nie zaś czymś.

Zdaniem Tischnera $\mathrm{z}$ opowieści o panu i niewolniku wyłania się obraz człowieka zawsze uwikłanego w bycie $\mathrm{z}$ innymi. Hegel zdaje się mieć rację, wiążąc sprawę wolności z byciem $\mathrm{w}$ relacji z innymi. Byt-dla-siebie może być sobą dzięki byciu-przez-innego. Bycie pojedynczym, jakie niesie przebywanie na pustyni czy w wysokogórskiej samotni, nie przynosi jeszcze wolności, lecz jedynie swawolę. I Hegel i Tischner są przekonani, że człowiek pełnej wolności nigdy nie będzie w stanie osiągnąć. Co prawda, dąży do niej, starając się uniezależnić od innych i od rzeczy będących przedmiotem pożądań, ale inni są mu potrzebni po to, by jego wolność została uznana ${ }^{19}$.

Wyzwalanie zaczyna się, gdy w niewolniku rodzi się myślenie. Odkrywa, że pan, by być panem, potrzebuje tego, kim mógłby władać. Myślenie kieruje go do idei, by być sobą przez siebie. Byt-przez-siebie, odrywając myśl od pętających go pożądań, zaczyna chcieć inaczej. Myślenie to pierw-

17 Alexander Kojève, Łączny komentarz do sześciu pierwszych rozdziałów „Fenomenologii ducha", tłum. Tadeusz Gadacz (Kraków: Wydział Filozofii Papieskiej Akademii Teologicznej, 1982).

18 Jean Hyppolite, Genèse et structure de la 'Phénoménologie de l'Esprit' de Hegel (Paris: Éditions Montaigne, 1946).

19 „Niewola na tym polega, że jest się w czyimś posiadaniu. Aby osiągnąć wolność, człowiek musi wybrać inne posiadanie niż to, w którym się znalazł. Musi się wznieść ponad siebie. Ale nigdy tak nie będzie, by posiadał, a sam nie był posiadany" [Tischner, Spowiedź, 23]. 
szy przejaw woli: „Myśleć to chcieć inaczej, a chcieć inaczej, to - myśleć”20. Zniewolony nie u siebie żyje - jest więc czyjś. Kto zaczyna myśleć, staje się wolny. Ale nie chodzi tu o zagłębienie się w przestrzeniach własnej fantazji. Rzecz nie wiąże się też z robieniem dowolnych rzeczy, ale z tym, że człowiek zaczyna rozumieć otaczającą go rzeczywistość. Oswaja świat, ubierając go w pojęcia. „Kiedy myślę, jestem wolny, ponieważ nie jestem wtedy u nikogo, ale jestem bezwzględnie u siebie samego, a przedmiot, który jest dla mnie istotą, jest moim bytem dla mnie w nierozdzielnej ze mną jedności. Mój ruch w pojęciach jest ruchem we mnie samym"21. Gdy siebie się nie posiada, to jakby się nie było. Pisze Hegel: „Na tym właśnie polega wolność, gdyż skoro jestem zależny, odnoszę siebie do czegoś innego, czym nie jestem, nie mogę istnieć bez czegoś zewnętrznego; jestem zaś wolny, gdy jestem u samego siebie"22.

Tischner uważa, że istota ludzka, by być człowiekiem, musi być wolna, czyli ma siebie mieć. „Bycie u siebie” to nie zdanie sprawozdawcze, ale zadaniowe. Człowiek jest sobie zadany. Wolność jest tam, gdzie jest swojość, a kończy się, gdzie zaczyna się „obcość”.

\section{Przestrzenie wolności według Józefa Tischnera}

Poglądy Tischnera na temat człowieka kształtowały się na przestrzeni wielu lat. Na początku swej filozoficznej działalności, idąc śladami Husserla, istotę człowieka wiązał $\mathrm{z}$ „Ja transcendentalnym”23. Potem dostrzegł rolę wartości w budowaniu wnętrza człowieka i uznał, że bardziej podstawowe jest „Ja aksjologiczne”24. W swej ostatniej filozoficznej pracy ${ }^{25}$ sformułował własną, bardzo ciekawą, koncepcję ,agatologicznej przestrzeni świadomo-

20 Tamże, 55.

${ }^{21}$ Hegel, Fenomenologia, t. 1, 231.

22 Georg Wilhelm Friedrich Hegel, Wykłady z filozofii dziejów, thum. Janusz Grabowski, Adam Landman (Warszawa: Państwowe Wydawnictwo Naukowe, 1958), 27. Po niemiecku: „Dies eben ist die Freiheit, denn wenn ich abhängig bin, so beziehe ich mich auf ein andres, das ich nicht bin; ich kann nicht sein ohne ein Äußeres; frei bin ich, wenn ich bei mir selbst bin".

${ }^{23}$ Józef Tischner, „Czym jest “Ja' transcendentalne?”, w: Szkice filozoficzne Romanowi Ingardenowi $w$ darze, red. Zofia Żarnecka (Kraków-Warszawa: PAX, 1964), 349-364.

24 Tischner, „Filozofia i ludzkie sprawy”, 109-125.

25 Tischner, Spór. 
ści”26 jako duchowego centrum człowieka. W tej koncepcji ważną rolę odgrywa sprawa wolności. Ale równie ważne jest tu to, co aksjologiczne i agatologiczne.

Głosząc, że człowieczeństwo związane jest z przestrzenią wolności, Józef Tischner nawiązuje do Jean-Paula Sartre'a. Przekonany jest jednak, że oprócz samego faktu wybierania istotne jest jeszcze to, co się wybiera. Wolność ma moc naznaczania (w sensie zostawiania znaków) i zmieniania rzeczywistości.

Takie spojrzenie na wolność pozwala dostrzec jej wielowymiarowość. Wolność istnieje nie tylko na płaszczyźnie ontologicznej - jest nicestwieniem i przekraczaniem tego, co jest - obecna twórczo jest także w obszarze agatologii. W człowieku bowiem oprócz wymiaru bytowego jest także wymiar związany z dobrem.

Według Józefa Tischnera dobro może powstawać dzięki wolności. I nie jest ono tożsame $\mathrm{z}$ bytem. Jego natura jest dynamiczna. Myślę, że można powiedzieć, iż ono istnieje na sposób „dobrzenia się”. Co mam na myśli? Zaistnienie dobra związane jest z człowiekiem oraz sposobem, $w$ jaki realizuje on swoją egzystencję. I ważniejsze w niej od relacji do rzeczy są odniesienia do innych ludzi. Stąd płynie konstatacja, że dobro pojawia się na sposób etyczny ${ }^{27}$.

Według Tischnera „cegiełkami” budującymi ten agatologiczny wymiar człowieka są wartości. One pojawiają się jako skutek tego, co rozgrywa się między człowiekiem a człowiekiem. Filozof widzi to następująco: człowiek często staje wobec ludzi zatroskanych, biednych, zagubionych... mówiąc krótko, wobec ludzi w potrzebie, czyli wobec tych, którzy sami nie dają sobie rady. Jeden człowiek, spotykając drugiego w potrzebie - symbolicznie Tischner określa go (za Levinasem) jako wdowę, sierotę i obcokrajowca musi podjąć decyzję, czy pomóc, czy przejść obojętnie. Poświęcić swoją uwagę i czas, czy dalej pozostawać w kręgu swoich spraw. Decyzja o pomocy wypływa, według Tischnera, z odkrycia w tym drugim dobra, które jest zagrożone. Ale decyzja to tylko pierwszy krok, a zadziałanie w celu pomocy, likwidacji tego, co drugiemu zagraża, wymaga również następnego

26 „Agatologiczna przestrzeń świadomości jest warunkiem możliwości człowieczeństwa w człowieku - jego bycia sobą jako człowieka. Dwa te pojęcia «człowieczeństwo» i «bycie sobą» traktujemy jako równoważne" [Tischner, Spór, 280].

27 Józef Tischner już w latach siedemdziesiątych pisał na przykład, że: „ofiara i poświęcenie są nieodłączne od ludzkiego życia moralnego" i „ofiara ludzka podjęta w imię dobra ma głęboki sens” [Józef Tischner, „Etyka wartości i nadziei”, w: Józef Tischner, Jan A. Kłoczowski, Wobec wartości (Poznań: W Drodze, 2001): 129]. 
kroku. Najpierw jest dostrzeżenie głodnego, a potem decyzja i nakarmienie go. Najpierw jest usłyszenie pytania błądzącego, potem decyzja o pomocy i naprowadzenie go na poszukiwaną drogę... Wybór to nie wszystko. Wartość rodzi się, gdy za wyborem idą konkretne działania „urzeczywistniające” wolę w przestrzeni świata.

To dzięki wolności człowiek może być współtwórcą, a nie trybikiem w wielkiej maszynerii świata. W przyrodzie rządzą prawa natury - chore, tak jak i stare, drzewo usycha, przewraca się i stopniowo zamienia w próchno, kamień spada po stoku w dół, nadejście zimowych mrozów sprawia, że woda zamienia się w lód... W świecie ludzkim także wiele dzieje się powodowane „siłą naturalnego bezwładu”. Ale dzięki wolności możne dziać się inaczej. Ona nie jest „zrozumianą koniecznością”. Dzięki wolności może, przynajmniej w niektórych obszarach, dziać cię inaczej. To człowiek ma moc działania wbrew „,naturze”. Przychodząc z pomocą, może sprawić, by głodny nie umarł z głodu, spragniony - z pragnienia, a strapiony znalazł pocieszenie i przestał się zamartwiać... Dzięki wolności bieg dziejów świata, w tym świata ludzkiego, może potoczyć się ,nienaturalnym” torem.

Tischner uważa, że na skutek zadziałania - nakarmienia głodnego, pokazania drogi zagubionemu, pocieszenia chorego - oprócz fizycznego (ważnego wszak) efektu pracy, pojawia się (równie ważny) efekt duchowy. Jest nim wartość. „Buduje się” ona na śladzie materialnym, czyli zmianie wprowadzonej przez człowieka w przestrzeni świata. Józef Tischner uważa, że ta wartość „istnieje” w dwóch przestrzeniach. Najpierw w przestrzeni fizycznej, jako zmiana w dotychczasowym porządku świata. I tu ma postać nakarmionego, pocieszonego albo wędrującego, już po właściwej drodze, człowieka. Jest też wymiar indywidualny. Tu wartość „istnieje” jako „,egiełka” budująca agatologiczne wnętrze człowieka. W kategoriach ontologicznych można powiedzieć, że dusza człowieka jest pustką. Nie jest natomiast pustką w wymiarach agatologicznych. Dusza jest przestrzenią zamieszkiwaną przez wartości. Są to wartości, które człowiek wybrał i doprowadził do ich realizacji. Powołał „do istnienia”, stając się ich „ojcem”. Są to jego wartości, bo przyswojone, budują jego dobro ${ }^{28}$. Dla Józefa Tischnera tylko to, co człowiek wybierze i zrealizuje w sposób wolny, jest jego. Zakotwiczenie

28 Tischner odróżnia dobro od wartości. Pisał: „Odkryciu wymiaru uczestnictwa w dobru zagraża uprzedmiotowienie w wartość. Od dłuższego już czasu utrzymuje się w filozofii dążenie do zastąpienia pojęcia dobra pojęciem wartości. Usiłuje się w ten sposób przybliżyć dobro doświadczeniu fenomenologicznemu. Czy jednak cel został osiągnięty? W istocie tym, co się osiąga, jest estetyzacja dobra” [Tischner, Spór, 177]. 
struktury ducha ludzkiego w wolności jest dla filozofa sprawą podstawową. Wielokrotnie cytował filozof myśl Hegla: ,jak substancją materii jest ciężar, tak substancją, istotą ducha jest wolność. [...] wszystkie właściwości ducha istnieją tylko dzięki wolności, są tylko środkami do wolności, wszystkie jej tylko poszukują i ją wytwarzają. Filozofia spekulatywna prowadzi do poznania, że jedynym prawdziwym znamieniem ducha jest wolność" 29 [wyróż. - Z. D.]. Ale wolność to nie swawola czy też „byle-cosiowatość”. By zrozumieć, na czym, według Józefa Tischnera, ona polega, należy przyjrzeć się jego koncepcji człowieka. „To [bowiem - Z. D.] człowiek jako taki jest wolnością i wyrazem wolności" 30 .

Istota człowieka jest nie natury bytowej, ale agatologicznej. Według Tischnera określenie „byt-dla-siebie” trafnie oddaje to, co stanowi o specyfice człowieka. Ale filozof podkreśla też, że człowiek jest również bytem-przez-siebie, to znaczy, że jest z tego, co sam wytworzył. A tym jest dobro, jego dobro. Pisze Tischner: „O słowie «mieć - posiadać» wiemy, że opisuje związek świadomości z tym, co dobre. Mam przede wszystkim to, co «odczuwam» jako dobre. Wtedy też jestem tym, co mam. [...] jestem tym, co mam, ponieważ to, co mam, jest dobre"31.

Według autora Sporu o istnienie czlowieka dusza nie jest formą ciała. Ona jest przestrzenią, którą „zamieszkują" różnorodne wartości powołane do istnienia przez człowieka. Są one różnej aksjologicznej „wagi”. Zatem dusza nie powinna być przedstawiana ani jako punkt, ani jako izomorficzna struktura.

Józef Tischner przez wiele lat uważał, że termin ,ja aksjologiczne"32 najtrafniej oddaje to, co stanowi centrum człowieka. Twierdził, że człowiek, wybierając i realizując wartości, „staje się tym, co ma wartość" ${ }^{33}$. Ale pomieszczone w Świecie ludzkiej nadziei opisy nie wskazują, że struktura Ja aksjologicznego jest zróżnicowana. Jest ona zatem izomorficzna i zwarta wewnętrznie - dlatego może być traktowana jak punktowa. Podobnie sam termin ,ja aksjologiczne” wydaje się wskazywać na jakąś zwartą istotność.

${ }^{29}$ Hegel, Wykłady, 26. Jak istotna jest ta myśl dla Tischnera, widać po częstotliwości jej przywołań w różnych tekstach. Na przykład w Sporze o istnienie człowieka Tischner przywołuje ten cytat wiele razy (np. na stronach 88, 134, 161, 284, 312), pojawia się on także w Spowiedzi rewolucjonisty (31).

30 Tischner, Spór, 161.

31 Tamże, 332.

32 Józef Tischner, „Genesis z ducha”, w: Józef Tischner, Świat ludzkiej nadziei (Kraków: Znak, 1975), 201-226.

33 Tamże, 220. 
Józef Tischner zaczął odchodzić od tego ujęcia i szukać bardziej adekwatnego po napisaniu Filozofii dramatu ${ }^{34}$. Wtedy odkrył, że aby wyjaśnić sposób, w jaki zło zawłaszcza człowieka, należy nieco inaczej spojrzeć na „konstrukcję” wnętrza człowieka. Dla sformułowania koncepcji agatologcznego wnętrza człowieka ważny jest także nieco wcześniejszy esej zatytułowany Myślenie wedtug wartości. Tu po raz pierwszy pojawia się wyjaśnienie, na czym polega doświadczenie agatologiczne, a na czym aksjologiczne ${ }^{35}$. Przełomowy jest jednak dopiero artykuł z 1992 roku zatytułowany Sprawa osoby - wstępne przybliżenie ${ }^{36}$. Jego uważna analiza pozwala uchwycić, jak rodziła się koncepcja agatologicznego centrum człowieka. „Przestrzenną” naturę wnętrza człowieka lepiej niż termin ,ja aksjologiczne" stara się filozof oddać terminami: „osoba agatoeidetyczna” i „egzystencja agatoeidetyczna”. W Sporze o istnienie czlowieka te terminy Tischner zastąpił (moim zdaniem trafniejszym) określeniem: ,agatologiczna przestrzeń świadomości”. Większość badaczy filozofii Józefa Tischnera dostrzega, że w końcowej fazie jego myślenie o człowieku ewoluowało ku agatologii. Jednak nowe centrum człowieka, przez analogie do określeń ,ja aksjologiczne” i ,ja transcendentalne”, określają oni terminem ,ja agatologiczne" - co w świetle dotychczasowuch ustaleń wydaje się niezasadne ${ }^{37}$.

Myślę, że można w oparciu o niektóre opisy - pomieszczone w rozdziale „Za istnieniem człowieka argument ontologiczny”38 - spróbować zrekonstruować model przestrzeni wewnętrznej człowieka opisany tylko w zarysie przez Józefa Tischnera. Wartości zamieszkujące wewnętrzną przestrzeń świadomości nie są rozlokowane przypadkowo. Efekty ludzkich wyborów i związanych z ich realizacją przeżyć „przedostają się” do duchowej przestrzeni człowieka w postaci wartości i „osadzają się” w niej. Ich rozlokowanie nie odbywa się na zasadzie chronologii czasowej czy też według ustalonej z zewnątrz, na przykład przez społeczeństwo lub też religię - ich „wagi”. W przestrzeni tej wartości zajmują miejsce według „zasady ważności”, budując jego (to jest tego konkretnego człowieka) wewnętrzne dobro.

34 Józef Tischner, Filozofia dramatu (Paryż: Éditions du Dialogue, 1990).

35 Józef Tischner, „Myślenie według wartości”, w: Józef Tischner, Myślenie według wartości (Kraków: Znak, 1982), 490-491.

36 Józef Tischner, „Sprawa”, 5-19.

37 Tak czyni na przykład Stefan Szary [Człowiek-podmiot dramatu (Kęty: Antyk, 2005)] oraz Agnieszka Wesołowska [Fenomenologia jako możliwość filozofii dramatu Józefa Tischnera (Katowice: Wydawnictwo Uniwersytetu Śląskiego, 2012)].

38 Tischner, Spór, 263-290. 
Przychodząca wartość sytuuje się tym bliżej centrum, im jest bliższa jego charakterowi. Jej obecność to wnętrze wzbogaca.

Stwierdzając, że człowiek wybiera, mając na względzie dobro, Tischner nawiązuje do koncepcji Tomasza z Akwinu. To dobro pojmuje jednak inaczej. O tym, czym to dobro jest, nie decyduje świat. Człowiek wybiera, jest wszak wolnością, i często jest to wybór wbrew światu i jego „sile ciążenia”. Wybiera w harmonii z dobrem, które „zamieszkuje” jego przestrzeń wewnętrzną. Wybór oglądany od strony wnętrza człowieka wygląda, jakby nie tyle polegał na dylemacie, co zrobić, ile powodował, że wartość, która może zaistnieć, lgnie do dobra, które już jest. To, co bytowo odmienne, ale agatologicznie pokrewne, dąży do spotkania, wzajemnego przyswojenia ${ }^{39}$. Pisze Tischner: „Wolność pozwala przyswajać, czyli sprawiać, że to, co pierwotnie nie było moje, jest moje. Przyswajanie nadaje sens wyborowi. Po co mianowicie miałoby się wybierać, gdyby za wyborem nie szło przyswajanie? Wybieramy tylko dlatego, że możemy przyswoić - coś sobie, ale i siebie czemuś. Przyswajanie jest zawsze wzajemne" 40 .

Jeśli dla lepszego zobrazowania sytuacji powiemy, że charakter wartości związany jest z barwą, to będzie to oznaczało, iż ,przybywająca” właśnie wartość, mająca barwę bliską najważniejszej barwy centrum, jeszcze bardziej ją wzmocni, a wartości o odleglejszej barwie uzupełniają ją o swój własny koloryt. O sile wewnętrznej przestrzeni świadomości decydują budujące ją wartości. Ale ponieważ te wartości różnią się od siebie w pewnym stopniu, to ta barwa, jaką wnętrze, a właściwie człowiek, świeci, nigdy nie jest monochromatyczna. Oglądany od strony ludzkiego wnętrza każdorazowy wybór i powiązane z nimi działanie jest skorelowane z charakterem, czyli barwą wartości, które zajmują centralną pozycję w wewnętrznej przestrzeni świadomości. Nadchodzące wartości o odleglejszej barwie z mniejszą mocą byłyby wybierane. A te o zupełnie innym charakterze - albo mówiąc innym językiem, o całkowicie obcej barwie - byłyby już w fazie wyboru odrzucane, nie byłyby więc realizowane. Czyli to dobro wewnętrzne - zbudowane z wartości, które człowiek sam wytworzył - kieruje jego wyborami i czynami.

To znaczy, że nie jest tak, jak twierdził Sartre, iż zasada wyboru jest całkowitą spontanicznością, wytryskującą z człowieka i w nieprzewidywalną

39 Bardziej obszernie o przyswajaniu i posiadaniu siebie samego w ujęciu Tischnera pisze Adam Workowski [„Etyczna wizja posiadania Józefa Tischnera”, w: Adam Workowski, Ontologiczne podstawy posiadania (Wrocław: Wydawnictwo Uniwersytetu Wrocławskiego, 2009), 212-222].

40 Tischner, Spór, 333. 
stronę ukierunkowującą jego aktywność. Według Tischnera to struktura agatologicznej przestrzeni wpływa na to, co człowiek wybierze w odpowiedzi na wyzwanie sytuacji spotkania. Wybory nie biorą się z ontologicznej nicości, lecz są powiązane z agatologiczną przestrzenią wewnętrzną człowieka. $\mathrm{Z}$ tym, co stanowi jego dobro naczelne.

\section{Inner Space of Freedom and the Issue of Man according to Józef Tischner (Summary)}

This article is an attempt to look at the views of Józef Tischner on the issue of freedom. According to the author, Tischner's way of thinking about that problem was most influenced by the views of three great European philosophers, Thomas Aquinas, Jean-Paul Sartre, and George Wilhelm Hegel. The author briefly discusses those theses that most inspired Tischner and those with which he polemicized. Tischner's views on the issue of freedom were not just a compilation of the views of those thinkers. The philosopher went his own way. He recognized that freedom is primarily connected with man and the various ways of his existence. Unlike Sartre, Tischner was convinced that free choice does not consist of a sudden unbounded act of choice. According to the Kraków philosopher, what is most important in freedom is connected with the spiritual side of man. A free choice springs from it. The inner space of freedom is of agathological character and is inhabited by values created by man. The characteristic of the inner space of freedom was only partly drawn by Tischner. Therefore, in the second part of the article, the author attempts to reconstruct Tischner's views on the structure of the 'agathological space of freedom'.

Keywords: freedom; issue of man; being-in-self; being-for-self; being-through-another; agathological space of consciousness; space of freedom.

\section{Wewnętrzna przestrzeń wolności \\ a sprawa czlowieka w ujęciu Józefa Tischnera (Streszczenie)}

Artykuł stanowi próbę przyjrzenia się poglądom Józefa Tischnera na kwestię wolności. Zdaniem autora na sposób myślenia Tischnera o tym problemie największy wpływ wywarły poglądy trzech wielkich filozofów europejskich, Tomasza z Akwinu, Jean-Paula Sartre'a i George Wilhelma Hegla. W artykule autor krótko 
omawia te tezy, które najbardziej go inspirowały, oraz te, z którymi polemizował. Poglądy Tischnera na kwestię wolności nie były kompilacją idei wspomnianych myślicieli. Filozof poszedł swoją drogą. Uznał, że wolność jest przede wszystkim związana z człowiekiem i różnymi sposobami jego egzystencji. Inaczej niż Sartre, Tischner był przekonany, że wolny wybór nie polega na nagłym, w niczym niezakorzenionym akcie wyboru. Według krakowskiego filozofa to, co najważniejsze w wolności, związane jest $\mathrm{z}$ duchową stroną człowieka. $\mathrm{Z}$ niej wyrasta wolny wybór. Wewnętrzna przestrzeń wolności ma charakter agatologiczny i zamieszkana jest przez wartości, których autorem jest człowiek. Charakterystyka wewnętrznej przestrzeni wolności została przez Tischnera jedynie częściowo zarysowana. Dlatego w drugiej części artykułu autor podjął próbę rekonstrukcji poglądów Tischnera na temat struktury ,agatologicznej przestrzeni wolności”.

Slowa kluczowe: wolność; sprawa człowieka; byt-w-sobie; byt-dla-siebie; bycie-przez-innego; agatologiczna przestrzeń świadomości; przestrzeń świadomości.

\section{Bibliografia}

Dymarski, Zbyszek. „Debata księdza Józefa Tischnera ze szkołą lubelską”. Logos $i$ Ethos 1 (1998): 235-245.

Kłoczowski, Jan Andrzej, Marek Drwięga, Karol Tarnowski, Jarosław Makowski. „Filozofia z wnętrza metafory”. Kontrapunkt (dodatek do Tygodnika Powszechnego) 10 (2000), (19.11.2000): 12-13.

Gilson, Étienne. Tomizm. Wprowadzenie do filozofi św. Tomasza z Akwinu, thum. Jan Rybałt. Warszawa: Instytut Wydawniczy PAX, 1960.

Hegel, Georg Wilhelm Friedrich. Fenomenologia ducha, thum. Adam Landman. Warszawa: Państwowe Wydawnictwo Naukowe, 1963.

Hegel, Georg Wilhelm Friedrich. Wyktady z filozofii dziejów, tłum. Janusz Grabowski, Adam Landman. Warszawa: 1958.

Hyppolite, Jean. Genèse et structure de la 'Phénoménologie de l'Esprit' de Hegel. Paris: Éditions Montaigne, 1946.

Kojève, Alexander. Łaczny komentarz do sześciu pierwszych rozdziałów „Fenomenologii ducha", thum. Tadeusz Gadacz. Kraków: Wydział Filozofii Papieskiej Akademii Teologicznej, 1982.

Panasiuk, Ryszard. „Ksiądz Tischner czyta Hegla”. W: Pytając o człowieka - myśl filozoficzna Józefa Tischnera, red. Władysław Zuziak, 33-42. Kraków: Znak, Wydział Filozoficzny Papieskiej Akademii Teologicznej, 2002. 
Sartre, Jean-Paul. Egzystencjalizm jest humanizmem, thum. Małgorzata Kowalska, Janusz Krajewski. Warszawa: Altaya \& DeAgostini, 2001.

Sartre, Jean-Paul. Byt i nicość, thum. Jan Kiełbasa i in. Kraków: Zielona Sowa, 2007.

Szary, Stefan. Człowiek - podmiot dramatu. Kęty: Antyk, 2005.

Tischner, Józef. „Czym jest ‘Ja’ transcendentalne?”. W: Szkice filozoficzne Romanowi Ingardenowi $w$ darze, red. Zofia Żarnecka, 349-364. Kraków-Warszawa: Państwowe Wydawnictwo Naukowe, 1964.

Tischner, Józef. Etyka a historia. Wykłady, red. Dobrosław Kot. Kraków: Znak, 2008. Tischner, Józef. „Etyka wartości i nadziei”. W: Józef Tischner, Jan A. Kłoczowski, Wobec wartości, 55-149. Poznań: W Drodze, 2001.

Tischner, Józef. Filozofia dramatu. Paryż: Éditions du Dialogue, 1990.

Tischner, Józef. Myślenie wedtug wartości. Kraków: Znak, 1982.

Tischner, Józef. „Schyłek chrześcijaństwa tomistycznego”. Znak 1 (1970): 1-26.

Tischner, Józef. „Sprawa osoby - wstępne przybliżenie”. Logos i Ethos 2 (1992): 5-19.

Tischner, Józef. Spowiedź rewolucjonisty. Kraków: Znak, 1993.

Tischner, Józef. Spór o istnienie czlowieka. Kraków: Znak, 1998.

Tischner, Józef. Świat ludzkiej nadziei. Kraków: Znak, 1975.

Tischner, Józef. Świat ludzkiej nadziei. Kraków: Znak, 1994.

Wesołowska, Agnieszka. Fenomenologia jako możliwość filozofii dramatu Józefa Tischnera. Katowice: Wydawnictwo Uniwersytetu Śląskiego, 2012.

Workowski, Adam. Ontologiczne podstawy posiadania. Wrocław: Wydawnictwo Uniwersytetu Wrocławskiego, 2009. 